\title{
Relationship Between ABO Blood Group and Migraine
}

\author{
Migren ve ABO Kan Grubu İlișkisi
}

\author{
$\underline{\text { Osman Korucu' }}^{1}$, Oktay Bulur ${ }^{2}$ \\ ${ }^{1}$ Keçiören Eğitim ve Araştırma Hastanesi, Nöroloji Kliniği \\ ${ }^{2}$ Keçiören Eğitim ve Araştırma Hastanesi, Dahiliye Kliniği
}

\begin{abstract}
Amaç: ABO kan grubu ile ilgili hastalıklar bulaşıcı hastalıklar (kolera, helicobacter pylori, echerichia coli), kardiyovasküler hastalık, maligniteler ve alerjik durumlardır. Çalıșmamızda ABO kan grubu ile migren arasındaki ilişkiyi araștırmayı amaçladık.

Materyal ve Metot: Nöroloji polikliniğinde Ocak 2008 ve Aralık 2018 tarihleri arasında migren tanısı almış ve kan grubu olan 985 erişkin hasta dosyası geriye dönük olarak incelendi. Hastane bilgi sisteminden hastaların yaş, cinsiyet ve kan grupları kaydedildi.

Bulgular: Hastalarda kan gruplarının dağılımı: A Rh+: $383(\% 38,89)$, A Rh-: 53(\%5,38), B Rh+: $148(\%$ 15,03), B Rh-: $16(\%$ 1,62), AB Rh+: 93(\%9,44), AB Rh-: 8(\% o,81), o Rh+: $257(\%$ 26,09), o Rh-: 27(\% 2,74) bulundu.

Sonuç: Çalışmamızda A Rh+ kan grubunun migren hastalarında en sık görülen kan grubu olduğunu bulduk.

Anahtar Kelimeler: Migren, ABO, Kan grubu
\end{abstract}

Objectives: Disorders related with $\mathrm{ABO}$ blood group are infectious disease (cholera, helicobacter pylori, echerichia coli), cardiovascular disease, malignancies and allergic status. We aimed to elucidate the association between $\mathrm{ABO}$ blood group and migraine.

Materials and Methods: We investigated retrospectively the files of 985 adult patients who were diagnosed with migraine and had blood type between January 2008 and December 2018 in neurology outpatient clinics included in the study. The age, gender and blood group of the patients scanned and recorded retrospectively from the hospital data system.

Results: Distribution of blood groups in patients as follows: A Rh+: $383(38.89 \%)$, A Rh-: $53(5.38 \%)$, B Rh+: 148 (15.03\%), B Rh-: 16(1.62\%), AB Rh+: 93(9.44\%), AB Rh-: 8(o.81\%), o Rh+: 257(26.09\%), o Rh-: $27(2.74 \%)$.

Conclusion: We found that in our study A Rh+ blood group was most prevalence blood group in migraine patients.

Keywords: Migraine, ABO, Blood Group

Yazışma Adresi / Correspondence:

Osman Korucu

Keçiören Eğitim ve Araștırma Hastanesi Nöroloji Kliniği, Ankara

e-mail: osmankorucu@yahoo.com

Date of submission: 07.08.2019

Date of admission: 28.08.2019

\section{Introduction}

After identification at the beginning of the 2oth century, blood groups were suggested to be associated with many diseases. Disorders related with ABO blood group are infectious disease (cholera, helicobacter pylori and Escherichia coli), cardiovascular disease, malignancies, thyroid diseases and allergic status. ${ }^{1-5}$ Despite the relation with diseases and blood groups has not been shown with certainty. Some researches postulated that $\mathrm{ABO}$ blood group antigens might be associated with general inflammatory response and single nucleotide polymorphisms in the $\mathrm{ABO}$ locus may increase TNF- $\alpha$ and soluble intercellular adhesion molecule-1 (ICAM-1) levels. ${ }^{6-10}$ In 
addition studies, were determined that there was an association between HLA antigens and ABO blood groups. ${ }^{11,12}$

Migraine is a one of frequent type of primary headache syndromes. It is an important cause of labour loss and reducing quality of life under the fifty years old. ${ }^{13}$ Studies aiming to determine the factors that plays role in migraine pathophysiology had showed multifactorial. These are genetic susceptibility, environmental factors, calcitonin gene related peptide, pituitary adenylate cyclase activating polypeptide, hormones, drugs and metabolism. ${ }^{14}$

There is not enough research to show the relation of $\mathrm{ABO}$ blood group and migraine. Our research aimed to clarify the effect of $\mathrm{ABO}$ blood group type on migraine.

\section{Materials and Methods}

We investigated retrospectively the files of 985 adult patients who were diagnosed with migraine and had blood type between January 2008 and December 2018 in neurology outpatient clinics included in the study. The age, gender and blood group of the patients scanned and recorded retrospectively from the hospital data system. There were no missing data. Yildız's study results used as a control study. ${ }^{15}$

Our study is a descriptive study and there were no exclusion criteria. Blood groups of cases assessed by the Invitrogel test system, MTC, Germany.

This study accepted by local ethics committee with the number: 022019/1830.

Normality of the distribution of the continuous variables was determined by the Kolmogorov-Smirnov test. Continuous variables with normal distribution were expressed as mean \pm SD. Variables with skew distribution were expressed as median (minimum-maximum), and categorical variables were expressed as percentage. We performed a chi-squared test for the comparison of two proportions (from independent samples), expressed as a percentage. Statistical analysis was performed with MedCalc Statistical Software version 18.11.3 (MedCalc Software bvba, Ostend, Belgium; https://www.medcalc.org; 2019) and SPSS 15.0 for Windows. P value < 0.05 was accepted as statistically significant.

\section{Results}

We analyzed 985 adult patients (age: median 37 (minimum 18, maximum 90 years old)), 907 of whom were female $(92.08 \%)$, and 78 of whom were male $(7.92 \%)$. Distribution of blood groups in patients as follows: A Rh+: $383(38.89 \%)$, A Rh-: 53(5.38 \%), B Rh+: 148(15.03\%), B Rh-: 16(1.62 \%), AB Rh+: 93(9.44\%), AB Rh-: 8(o.81 \%), o Rh+: 257(26.09\%), o Rh-: 27 (2.74\%). (Table 1)

When we compare $\mathrm{ABO}$ blood groups in migraine patients and control group according to gender. There was no significant difference between migraine patients and control study in males(p>0.05). However, in female migraine patients, $A$ and $A B$ blood groups were significantly higher than control study $(\mathrm{p}=0.001 / \mathrm{p}=0.018)$. Whereas $\mathrm{O}$ and $\mathrm{B}$ groups were significantly lower in female migraine patients $(\mathrm{p}=0.001 / \mathrm{p}=0.035)$. When groups compared by Rh status there was not statistically significant difference between migraine patients and control study results. (Table 2-3) 
Table 1. Distribution of Patients' Blood Groups According to Gender

\begin{tabular}{|c|c|c|c|c|c|c|c|c|c|}
\hline \multirow[b]{2}{*}{ Gender } & \multicolumn{8}{|c|}{ Blood Group } & \multirow[b]{2}{*}{ Tota } \\
\hline & $\begin{array}{c}\text { A Rh+ } \\
\mathrm{n} \\
(\%)\end{array}$ & $\begin{array}{c}\text { A Rh- } \\
\text { n } \\
(\%)\end{array}$ & $\begin{array}{c}\text { B Rh+ } \\
\mathrm{n} \\
(\%)\end{array}$ & $\begin{array}{c}\text { B Rh- } \\
\text { n } \\
(\%)\end{array}$ & $\begin{array}{c}\mathrm{O} \mathrm{Rh}+ \\
\mathrm{n} \\
(\%)\end{array}$ & $\begin{array}{c}\text { O Rh- } \\
\mathrm{n} \\
(\%)\end{array}$ & $\begin{array}{c}\text { AB Rh+ } \\
\text { n } \\
(\%)\end{array}$ & $\begin{array}{c}\text { AB Rh- } \\
\mathrm{n} \\
(\%)\end{array}$ & \\
\hline Fem & $\begin{array}{c}357 \\
(39 \cdot 37)\end{array}$ & $\begin{array}{c}49 \\
(5.40)\end{array}$ & $\begin{array}{c}134 \\
(14.77)\end{array}$ & $\begin{array}{c}15 \\
(1.65)\end{array}$ & $\begin{array}{c}234 \\
(25.80) \\
\end{array}$ & $\begin{array}{c}26 \\
(2.87)\end{array}$ & $\begin{array}{c}85 \\
(9 \cdot 37)\end{array}$ & $\begin{array}{c}7 \\
\text { (o.77) }\end{array}$ & 907 \\
\hline Male & $\begin{array}{c}26 \\
(33.33) \\
\end{array}$ & $\begin{array}{c}4 \\
(5.13) \\
\end{array}$ & $\begin{array}{c}14 \\
(17.95) \\
\end{array}$ & $\begin{array}{c}1 \\
(1.28) \\
\end{array}$ & $\begin{array}{c}23 \\
(29.49) \\
\end{array}$ & $\begin{array}{c}1 \\
(1.28) \\
\end{array}$ & $\begin{array}{c}8 \\
(10.26) \\
\end{array}$ & $\begin{array}{c}1 \\
(1.28)\end{array}$ & 78 \\
\hline
\end{tabular}

Comparison of total numbers in $\mathrm{ABO}$ groups and Rh status, $\mathrm{A}$ and $\mathrm{AB}$ blood group was significantly higher in migraine patients $(\mathrm{p}=\mathrm{0.001})$. Nevertheless o blood group and $\mathrm{Rh}$ status ratio was lower than the control study $(\mathrm{p}=0.604)$. (Table 4-5)

Table 2. ABO blood group comparison according to gender

\begin{tabular}{|c|c|c|c|c|c|c|}
\hline \multirow{2}{*}{ Gender } & \multirow{2}{*}{ ABO Group } & \multicolumn{2}{|c|}{ Results } & \multicolumn{2}{|c|}{ Control study } & \multirow[b]{2}{*}{$\mathbf{p}$} \\
\hline & & $\mathbf{n}$ & $\%$ & $\mathbf{n}$ & $\%$ & \\
\hline \multirow{5}{*}{ Female } & $\mathrm{A}$ & 406 & 44.76 & 493 & 35.96 & $0.001^{*}$ \\
\hline & $\mathrm{O}$ & 260 & 28.67 & 505 & 36.84 & $0.001^{*}$ \\
\hline & $\mathrm{B}$ & 149 & 16.43 & 273 & 19.91 & 0.035 \\
\hline & $\mathrm{AB}$ & 92 & 10.14 & 100 & 7.29 & $0.018^{*}$ \\
\hline & Total & 907 & 100 & 1,371 & 100 & \\
\hline \multirow{5}{*}{ Male } & A & 30 & 38.46 & 52,445 & 38.99 & 0.942 \\
\hline & $\mathrm{O}$ & 24 & 30.77 & 49,914 & 37.12 & 0.249 \\
\hline & $\mathrm{B}$ & 15 & 19.23 & 22,822 & 16.97 & 0.587 \\
\hline & $\mathrm{AB}$ & 9 & 11.54 & 9,304 & 6.92 & 0.109 \\
\hline & Total & 78 & 100 & 134,485 & 100 & \\
\hline
\end{tabular}

Table-3: Rh groups comparison according to gender

\begin{tabular}{|c|c|c|c|c|c|c|}
\hline \multirow{2}{*}{ Gender } & \multirow{2}{*}{$\mathbf{R h}$} & \multicolumn{2}{|c|}{ Results } & \multicolumn{2}{|c|}{ Control study } & \multirow[b]{2}{*}{$\mathbf{p}$} \\
\hline & & $\mathbf{n}$ & $\%$ & $\mathbf{n}$ & $\%$ & \\
\hline \multirow{3}{*}{ Female } & Rh positive & 810 & 89.31 & 1196 & 87.20 & \multirow{3}{*}{0.131} \\
\hline & Rh negative & 97 & 10.69 & 175 & 12.80 & \\
\hline & Total & 907 & 100 & 1371 & 100 & \\
\hline \multirow{3}{*}{ Male } & Rh positive & 71 & 91.03 & 120,902 & 89.90 & \multirow{3}{*}{0.746} \\
\hline & Rh negative & 7 & 8.97 & 13,583 & 10.10 & \\
\hline & Total & 78 & 100 & 134,485 & 100 & \\
\hline
\end{tabular}

\section{Discussion}

We found that in our study A Rh+ blood group was most prevalence blood group in migraine patients. Geographical location and the ethnicity effects the ABO blood group dispersion. ${ }^{16}$ There are several epidemiological researches about blood group 
distribution in Turkey. In the east and west providence of Turkey blood group dispersion is $\mathrm{A}, \mathrm{O}, \mathrm{B}, \mathrm{AB}$ respectively. ${ }^{17-18}$ This order was consistent with our findings.

Table 4. Comparison of total numbers in ABO groups

\begin{tabular}{|c|c|c|c|c|c|}
\hline \multirow{2}{*}{ ABO Group } & \multicolumn{2}{|c|}{ Results } & \multicolumn{2}{|c|}{ Control study } & \multirow[b]{2}{*}{$\mathbf{p}$} \\
\hline & $\mathbf{n}$ & $\%$ & $\mathbf{n}$ & $\%$ & \\
\hline A & 436 & 44.26 & 52,938 & 38.97 & $0.001^{*}$ \\
\hline $\mathrm{O}$ & 284 & 28.83 & 50,419 & 37.11 & $0.001^{*}$ \\
\hline B & 164 & 16.65 & 23,095 & 17 & 0.739 \\
\hline $\mathrm{AB}$ & 101 & 10.26 & 9,404 & 6.92 & $0.001^{*}$ \\
\hline Total & 985 & 100 & 135,856 & 100 & \\
\hline
\end{tabular}

Table 5. Comparison of total numbers in Rh status

\begin{tabular}{|l|c|c|c|c|c|}
\hline \multirow{2}{*}{ Rh } & \multicolumn{2}{|c|}{ Results } & \multicolumn{2}{c|}{ Control study } & \\
\cline { 2 - 5 } & $\mathbf{n}$ & $\mathbf{\%}$ & $\mathbf{n}$ & $\mathbf{0}$ & $\mathbf{p}$ \\
\hline Rh positive & 881 & 89.44 & 122,098 & 89.87 & \\
\hline Rh negative & 104 & 10.56 & 13,758 & 10.13 & \multirow{2}{*}{0.604} \\
\hline Total & 985 & 100 & 135,856 & 100.0 & \\
\hline
\end{tabular}

Although the relation between $\mathrm{ABO}$ blood groups and different diseases was investigated in several animal and human studies, there are very few studies about ABO blood groups and migraine or neurological diseases. In 1976 Mehne et al. considered blood groups might have an effect on Alzheimer pathogenesis, Renvoize advocated the opposite. ${ }^{19-20}$ Massimo Franchini and friends showed the $\mathrm{O}$ blood group is protective against neurodegenerative diseases in their study. ${ }^{21}$ In our literature inquiry, we found only one article that searches migraine and blood group link. This study reported prevalence of migraine was highest in $\mathrm{O}$ blood group. ${ }^{22}$

When we consider the pathogenesis of migraine, we think that the antigenic structure of blood groups may be effective in this process.

\section{References}

1. Anstee DJ. The relationship between blood groups and disease. Blood. 2010;115:4635-43.

2. Liumbruno GM, Franchini M. Beyond immunohaematology: the role of the ABO blood group in human diseases. Blood Transfus. 2013;11(4):491-9.

3. A Hong Kong tuberculosis treatment services/British medical research council investigation. Investigations of allergic status and blood counts in Chinese patients receiving daily or intermittent rifampicin in Hong Kong. Clin Allergy. 1975;5(2):189-99.

4. Pourafkari L, Ghaffari S, Ahmadi M, Tajlil A, Nader ND. Association of ABO blood types with the risk of in-stent restenosis. Perfusion. 2015;30(6):507-13.

5. Dagdeviren M, Ates I, Demir BF, Ergun E, Yildiz C, Altay M. Investigation of blood groups in benign thyroid diseases in Turkey. Endocr J. 2019 Jul 12. doi: 10.1507/endocri.EJ18-0582. [Epub ahead of print]

6. İslamoğlu ZGK, Unal $\mathrm{M}$. Is there an association of $\mathrm{ABO}$ blood groups and Rhesus factor with alopecia areata? J Cosmet Dermatol. 2018;17:1271-4. 
7. Pare G, Chasman DI, Kellogg M, Zee RY, Rifai N, Badola S, et al. Novel association of ABO histoblood group antigen with soluble ICAM-1: results of a genome-wide association study of 6,578 women. PLoS genetics. 2008;4(7):e10oo118.

8. Melzer D, Perry JR, Hernandez D, Corsi AM, Stevens K, Rafferty I, et al. A genome-wide association study identifies protein quantitative trait loci (pQTLs). PLoS genetics. 2008;4(5):e1000072.

9. Park EJ, Lee JH, Yu GY, He G, Ali SR, Holzer RG, et al. Dietary and genetic obesity promote liver inflammation and tumorigenesis by enhancing IL-6 and TNF expression. Cell. 2010;140(2):197208.

10. Balazs C. The role of hereditary and environmental factors in autoimmune thyroid diseases. Orvosi hetilap. 2012;153(26):1013-22.

11. Valikhani M, Kavand S, Toosi S, Kavand G, Ghiasi M. ABO blood groups, Rhesus factor and pemphigus. Indian J Dermatol. 2007;52:176-8.

12. Eiermann T.H., Vejbaesya S., Prestel H, Roepke A, Muller-Myhsok B., Schmitt-Egenolf M. Association and linkage of human leukocyte antigens with psoriasis-revisited. Infus Ther Transfus Med. 2002;29:326-30.

13. Olesen J. International Classification of Headache Disorders. Lancet Neurol. 2018;17(5):396-7.

14. Charles A. The pathophysiology of migraine: implications for clinical management. Lancet Neurol. 2018;17(2):174-82.

15. Yıldız ŞM. Distribution of ABO and Rh blood group systems in Cukurova region. Cukurova Med J 2016;41(4):658-63.

16. Beardmore JA, Karimi-Booshehri F. ABO genes are differentially distributed in socio-economic groups in England. Nature. 1983;303(5917):522-4.

17. Galip Akın ND. Türkiye'de kan grubu araştırmaları. Ankara Üniversitesi Dil ve Tarih-Coğrafya Fakültesi Dergisi. 2005;45(2):1-15.

18. Demet Özdemir HE, Aysenur Ucar. Blood Groups Distributions of Donors/Patients in a Tertiary Hospital. Sakarya Med J. 2018;8(4):753-8.

19. Mehne P, Grunwald P, Gerner-Beuerle E. A serogenetic approach to the study of Alzheimer's disease (author's transl). Aktuelle Gerontol. 1976;6(6):259-66.

20. Renvoize EB. ABO and Rhesus blood groups in Alzheimer's disease. Age Ageing. 1985;14(1):43-5.

21. Franchini M, Liumbruno GM. ABO blood group and neurodegenerative disorders: more than a casual association. Blood Transfus. 2016;14(2):158-9.

22. Nishi K., Gupta N.K., Sharma S.C. Study on the Incidence of Hypertension and Migraine in ABO Blood Groups. ISCA Journal of Biological Sciences. 2012;1(2):12-6. 